\title{
Letters
}

Website: bmj.com

Email: letters@bmj.com

\section{Letter from Afghanistan}

EDITOR-After 23 years of war and three years of drought Afghanistan has been driven into sweeping devastation and poverty. Having spent two weeks in Afghanistan on behalf of the US Physicians for Human Rights, as a member of a three person team, I can say that unless the international community moves rapidly to extend a security network outside Kabul and to mobilise funds for short term projects, the military and political investment in the coalition war will have been for naught.

Curfews imposed since the time of the Russians close down the cities at $10 \mathrm{pm}$, but the United Nations keeps its staff in after nightfall, even in Kabul. At least Kabul can point to the international security force, albeit thinly deployed. Elsewhere, the only restraint is the presence of coalition forces at the airports or in temporary bivouacs, and these troops are poised to leave at any time.

Mazaar-I-Sharif, the main city of the north, is divided into three distinct sections under the direction of three rival warlords. Virtually every male aged 14 to 60 in this city carries a Kalashnikov rifle. To venture out after nightfall is to contend with packs of howling dogs and encounters with wayward armed men, possibly allied with a warlord,

\section{Advice to authors}

We prefer to receive all responses electronically, sent directly to our website. Processing your letter will be delayed unless it arrives in an electronic form.

We are now posting all direct submissions to our website within 24 hours of receipt and our intention is to post all other electronic submissions there as well. All responses will be eligible for publication in the paper journal.

Responses should be under 400 words and relate to articles published in the preceding month. They should include $\leqslant 5$ references, in the Vancouver style, including one to the BMJ article to which they relate. We welcome illustrations.

Please supply each author's current appointment and full address, and a phone or fax number or email address for the corresponding author. We ask authors to declare any competing interest. Please send a stamped addressed envelope if you would like to know whether your letter has been accepted or rejected.

Letters will be edited and may be shortened.

bmj.com

letters@bmj.com possibly simple bandits. Incidents of assault and robbery are increasing daily in every urban area. Checkpoints have sprung up along the roads leading out from every city and town in the north, and it is unclear, as you approach, what will be exacted in order to pass. Everyone we spoke to is afraid of a return to the murderous times of the 1992-6 civil wars.

The relief that people have expressed in watching the Taliban flee is fading quickly into fear of what may happen if the warlords are allowed free rein. In a country where people have seen nothing but conflict they plead first for a neutral and professional external force to help stabilise their early and fragile peace.

They then plead for an urgent infusion of relief aid and the start of practical visible reconstruction projects. Currently in Kabul there is electricity for a few hours every other day. The northern city of Mazaar also occasionally has electricity. Generators are few; fuel expensive. Food is present in the markets, but the prices are high. Cooking and heating rely on thin metal stoves, stoked with diesel burners or gnarled thick wood from the dead grapevines and orchards of the once verdant fields and plains. There is no running water in these cities. There is also no police force, sanitation service, refuse collection, or postal service.

Entire commercial and residential sections of Kabul stand like ancient ruins, the result of murderous cross bombardment in the days of the Mujahadeen. Similar swathes of destruction mar extensive areas of Mazaar, where the Taliban assaulted neighbourhoods, slaughtered civilians, and bulldozed every structure.

In these cities the parks are dust, the remaining trees barely standing with the lack of rain. Very limited access to the villages and hamlets that lie days off the main roads (and these roads themselves are almost impassable because of war damage and neglect) makes it most difficult to generalise about conditions of rural life.

There are few reliable data on the demographic, economic, and social situation of the Afghans. UN surveys suggest that landmines and unexploded ordnance still litter vast areas of arable and grazing land and that $\$ 668 \mathrm{~m}$ will be needed in the next seven years to make that land usable and safe (UN mine action programme, personal communication). Added to this total are the costs of dealing with the cluster bomb contamination and equipment loss from the coalition aerial bombardment.

Unemployment is rampant throughout the country (the demining enterprise is the largest employer, with 5000 local staff). The lack of jobs is said to swell the ranks of the warlord armies, the only game in town. Health conditions are dire; immunisation rates have fallen to $17 \%$ of eligible children, serious malnutrition and micronutrient deficiencies have been found in sample surveys, ${ }^{1}$ infant mortality is estimated to be 165 per 1000; maternal mortality is thought to be among the highest in the world (1700 per 100000 live births). ${ }^{2}$

We met ministers, community leaders, staff from local and international nongovernmental organisations, doctors and healthcare workers, and officials with international organisations. All placed high priority on a few key infrastructure tasksrebuild roads, restore water and sanitation systems, install generators for public buildings, hospitals, and schools. The request to the international community is to bring in the money and expertise to help direct local Afghans in getting this work accomplished.

There are other needs as well-helping to set up an administrative, banking, and legal system; providing training to medical and public health staff; fitting out hospitals and clinics; bringing in basic medical equipment and supplies.

What does not need to be done is instil a sense of hope, energy, and resilience. These core human capacities can be found in abundance in Afghanistan-still, despite all these years. But the window of opportunity will not stay open for long. People cling to the faith that those who drove out the Taliban will now stay and help them rebuild their country. The memory is still fresh, however, of the last time the international community came and then left far too quickly. This memory clouds all current expressions of optimism. If history seems to be repeating itself, there is no telling how much farther Afghanistan might yet fall.

Jennifer Leaning professor of international health Harvard Medical School, Harvard School of Public Health, 651 Huntingdon Avenue, Boston,

MA 02115, USA

$\mathrm{JL}$ is a member of the board of directors of the Physicians for Human Rights.

1 Assefa F, Jabarkhil MZ, Salama P, Spiegel P. Malnutrition and mortality in Kohistan district, Afghanistan, April 2001. JAMA 2001;286:2723-8.

2 ReliefWeb. WHO country data. Available at reliefweb.org (accessed 21 Jan 2002). 


\section{Israeli-Palestinian conflict}

See news article by Ferriman

Need for medical services for Palestinians injured in West Bank is urgent

EDITOR-The most recent toll of injuries among Palestinians in the West Bank and Gaza Strip during the current Al-Aqsa Intifada is 32849 , or 9.9 per 1000 population. ${ }^{1}$ Data from just over a year ago show that of the 6071 injured from 28 September till the end of December 2000, 789 were expected to have permanent disability, a rate of 263 per month, or $13 \%$. Similar rates have been noted by other sources. ${ }^{23}$ This is equivalent to 7890 people becoming disabled every month in the United Kingdom.

Analysis of the pattern of injuries in last year's data shows why the rate of disability is so high. People under 35 were most likely to be injured. Of the 6071 injured, 226 were aged $0-11$ years, 1297 were aged $12-17$, and 3535 were aged 18-34 compared with 414 aged 35-49 and 599 aged 50 or over. In addition, both the type of weapon used and the site of injury show the potential for a high rate of disability. ${ }^{45} \mathrm{In}$ all, 1418 people were hit by live, mainly American-made, M-16 bullets, which often break into tiny pieces and cause multiple internal injuries, and 1936 were hit by rubber coated metal bullets, which can cause extensive damage when fired at short range. Half of the injuries (3032) were to the upper part of the body, including the head, and nearly a quarter (1403) to the lower part, including the pelvis.

The long term needs of disabled people are great in all health systems. In the West Bank only the largest of the three nongovernmental rehabilitation centres has been able to increase its beds from 22 to 30 . Community based rehabilitation is constrained by the overwhelming medical needs of those injured and by the isolation and separation of cities and villages imposed by the Israeli army as a form of collective punishment.

The international community needs to call for an immediate end to the occupation of the West Bank and Gaza Strip. Local and international policymakers need also to develop urgently the service for and care of disabled people, both qualitatively and quantitatively, to deal with this pressing humanitarian problem.

Samia O Halileh assistant professor

Institute of Community and Public Health, Birzeit University, PO Box 14, Birzeit, West Bank, Palestine samia@birzeit.edu

I acknowledge the work of Amal R Daoud, Rana A Khatib, and Nahed S Mikki for their contribution to the original article that led to this letter.

1 Palestinian Central Bureau of Statistics. Population in the Palestinian Territory, 1997-2025. Ramallah: PCBS, 1999. Also Ministry of Health website www.moh.gov.ps/update/ totalmartyr.html (accessed 28 Jan 2002).

2 HDIP. Health care under siege II: The health situation of Palestinians during the first two months of the Intifada: HDIP, 2000 3 Ministry of Health. Cumulative data analysis until 8 January 2001. Available at http://www.pna.org/moh/ alaqsa_stat0801.htm (accessed 2 Mar 2001).

4 Richburg K. Young Palestinians suffer bone-shattering experience. Washington Post Foreign Service 2000; 30 Nov.

5 Goldenberg S. Israel shifts to live bullets: assassinations

and gunfire into mobs take rising Arab toll. Guardian 2000; 28 Nov.

\section{Health consequences of Israeli} settlements in occupied lands

EDITOR-Can people believe in the olive branch, the symbol of peace, in the Middle East? So many olive trees have been felled to make room for Israeli settlements in the occupied territories, West Bank, and Gaza Strip. These settlements seem increasingly to be a root cause of the terrorist activities practised by both sides. Whereas terrorism quickly makes headlines in the media, the idea of settlements is innocuous to many people. The settlements are, however, far more destructive to the peace process and have much more serious and long term consequences than the loss of life through terrorism.

The settlements are a clear breach of the Fourth Geneva Convention, which states that an occupying power must not transfer parts of its own civilian population to occupied areas. ${ }^{1}$ Nevertheless, the Israeli settlements were established soon after the war in 1967 and have grown ever since.

The settlers' houses are built mainly on the hilltops. Water and electricity are installed and a sewage system is established, often with an outlet for draining untreated sewage into the valleys. Nearly 400000 settlers use the same amount of water as 3 million Palestinians. In Gaza around 6500 settlers surrounded by security zones use more than $40 \%$ of the area while the 1.1 million Palestinians are crowded into the remaining $55-60 \%$.

The fast growing settlements gradually encroach on the Palestinian villages, often isolating them from their surroundings. Palestinians require special permits to travel between the Palestinian administered areas, and Israeli soldiers check the permits at the many control posts.

Health services are affected. Passage has been denied several times to ambulances in times of great need-sometimes with fatal consequences. $^{23}$ Hospitals, clinics, and ambulances are targets for the Israeli military forces and for settlers, many of whom carry arms.

The occupation has several indirect health consequences. ${ }^{3}{ }^{4}$ For example, the incidence of psychiatric conditions has doubled, mainly in children. Difficult road conditions mean that neither health staff

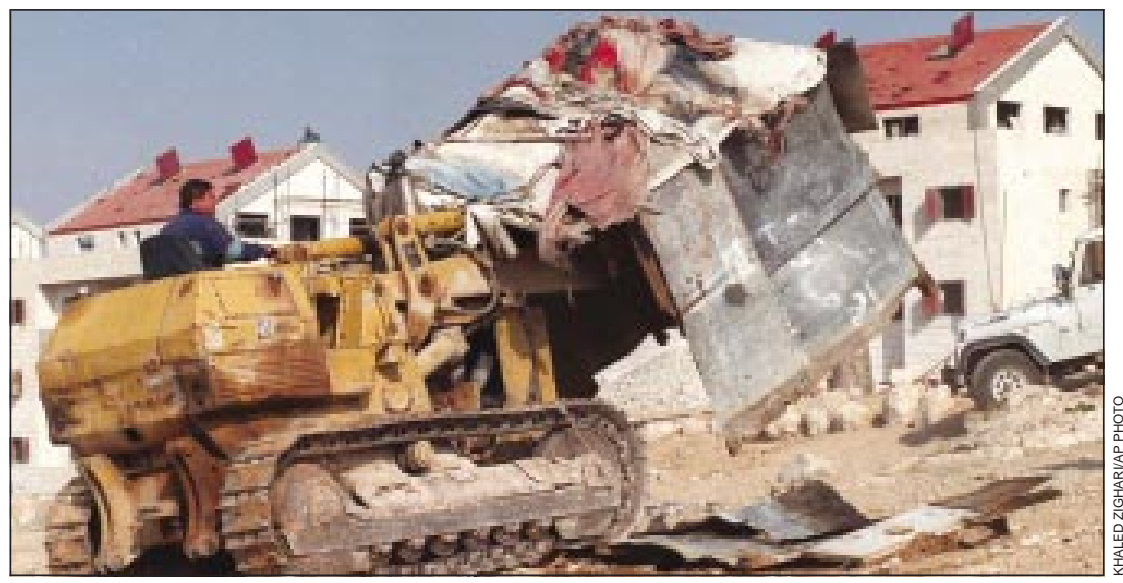

A bedouin shack is removed from the outskirts of the Jewish settlement of Maale Adumim, near Jerusalem nor patients can reach hospitals, maternity wards, or clinics. Distribution of drugs is difficult. Vaccination programmes cannot be carried out satisfactorily. United Nations supply trucks cannot circulate unhindered. Some villages are so effectively cut off from the outside world that food is limited.

Ole J Hartling consultan

Vejle Hospital, DK-7100 Vejle, Denmark oha@vs.vejleamt.dk

OJH is a member of Physicians for Human Rights/ Denmark, the Danish Medical Group of Amnesty International, and the Danish parliament's ethical committee.

1 United Nations Security Council. Resolution 1322. Adopted by the Security Council at its 4205th meeting on 7 October 2000. New York: UN, 2000. (S/RES/1322.)

2 B'Tselem. Information sheet June 2001. Jerusalem: Israeli Information Centre for Human Rights in the Occupied Territories, 2001:8-9. High Commissioner for Human Rights and follow-up to the world conference on human rights. Question on the violation of human rights in the occupied Arab territories, including Palestine. New York: United Nations Economic and Social Council, 2001:1-28. (E/CN.4/2001/114.)

4 World Health Organization. Health conditions of, and assistance to, the Arab population in the occupied Arab territories, including Palestine. Geneva: WHO, 2001.

\section{Conflict in Sri Lanka}

\section{Sri Lanka's health service is a casualty of} 20 years of war

EDITOR-Sri Lanka's 20 years of war has killed over 60000 people and displaced hundreds of thousands more. The LTTE (the Liberation Tigers of Tamil Eelam) has been fighting for its own state, resulting in areas of permanent conflict in the north and east of the country. Civilians are caught in crossfire; landmines and unexploded ordnance pose a constant threat; hospitals have been destroyed.

Médecins Sans Frontières runs a substitution medical programme in the northern rebel controlled area, known as the Wanni, supplying specialists, including a surgeon, a paediatrician, an obstetrician, and an anaesthetist. Most medical professionals have fled: 21 of the 27 vacancies for government doctors in the region remain vacant, and only 34 of the 108 midwife positions are filled (rates of maternal and neonatal death are
3 Commission on Human Rights. Report of the United Nations 
higher than the national average). Government training of medical workers has not taken place in the region since the war began.

Population displacement has led to a rise in infectious diseases and malnutrition. As a result, malaria has increased 20-fold since the conflict began owing to disrupted vector control activities and limited access to treatment facilities, being among the leading causes of death in some areas.

For seven years many essential supplies to the Wanni, including basic items such as sutures, surgical gloves, and oxygen, were subject to government embargo, and drugs and medical materials are often critically low. No postoperative analgesics are available, and often only life saving essential surgery can be performed.

In sharp contrast to many other conflicts, humanitarian law is for the most part respected: soldiers fight soldiers. Both sides cooperate on certain health issues such as emergency patient transfers across the front line and temporary ceasefires to allow polio immunisation campaigns to take place for children.

Sri Lanka's conflict seems nationally and internationally to be have been accepted as a chronic, ethnic conflict, but there are signs of improvement. In January the government embargo was lifted, and previously limited medical supplies are beginning to become available, albeit sporadically. Medical transfers should now be easier. Peace talks are planned.

More could be done to protect the health of civilians. Official training leading to government certification should be given in the rebel controlled area to meet the acute demand for medical staff, and the LTTE should assume greater responsibility for health care in regions under its control. In Sri Lanka as elsewhere, the terrible damage caused by the war to people's health and life expectancy should not be accepted as an inevitable consequence of the fighting.

Brigg Reilley epidemiologist

Isabel Simpson head of mission

Médecins Sans Frontières, Colombo, Sri Lanka

Nathan Ford access to medicines adviser

Médecins Sans Frontières, London EC1R 5DJ

office@london.msf.org

Marc DuBois humanitarian affairs adviser

Médecins Sans Frontières, Amsterdam,

the Netherlands

\section{Doctors can influence people and promote peace}

EDITOR-Sri Lanka has been ravaged by an internal war for nearly 20 years, with the loss of thousands of lives. Efforts at a negotiated settlement have failed repeatedly.

In this scenario, a workshop on health as a bridge for peace (sponsored by the World Health Organization and approved by the national health authority) was held in 2001. It was mainly for health professionals working in key areas, including in the conflict zones, and many of the issues raised in Vass's editorial, "Peace through health," were discussed. There seemed to be a consensus among the participants that health professionals should create opportunities for peace through health.
In Sri Lanka a truce has been negotiated regularly by Unicef to conduct immunisation programmes. Health professionals continue to work in conflict areas amid considerable risk to their lives. Doctors from the Sinhalese majority working in hospitals in predominantly minority regions have often been able to build bridges of better understanding among communities segregated on ethnic lines. By virtue of their training they can rise above racial and communal barriers.

Health professionals also see at first hand the physical and psychological trauma wrought by the war and can raise nationa awareness on suffering related to war. They have also been a voice against child soldiers.

We believe that lack of conclusive evidence of the benefits of health initiatives for achieving peace is linked to lack of experimentation. When serving in conflict zones young doctors need to be aware of their role to promote peace while avoiding the inherent dangers that compromise their professional standing.

In most developing countries, including Sri Lanka, doctors are generally held in high esteem and their opinion is respected. Through their actions they are in a position to influence people. The principles of conflict resolution have been noted for inclusion in the behavioural sciences module of the medical curriculum in Sri Lanka

K A L A Kuruppuarachchi senior lecturer in psychiatry

lalithkuruppu@lycos.com

S S Williams lecturer in psychiatry

Department of Psychiatry, Faculty of Medicine,

University of Kelaniva, PO Box 6, Ragama,

Sri Lanka

1 Vass A. Peace through health. BMJ 2001;323:1020. (3 November.)

2 De Silva DGH, Hobbs CJ. Conscription of children in armed conflict. BMJ 2001;322:1372

\section{To combat terrorism, United Nations must be in charge}

EdiToR-I agree with Holdstock that appeasement does not always work, ${ }^{1}$ but the current "war on terrorism" will not work either. Apart from innocent children, women, and men being killed-cynically called collateral damage- by the dropping of expensive bombs, the high tech warfare destroys remnants of infrastructure in an already devastated country, produces martyrs, and infuriates Muslims all over the world, with unknown consequences. The third world war? Clash of civilisations? Apocalypse? Naive waffling?

An international court of justice needs to be in charge for trials against terrorism, for it was the international community that was hit in New York. United Nations forces should deliver the culprits, to stand trial.

In an ideal world we in the First World will understand that present injustices (standard of living, life expectancy, use of resources) cannot continue without severe conflicts. The problems are bound to get worse, not better, if we do not tackle the roots now. But 1 in 4 children in the United Kingdom lives below the poverty line, so how are we going to change the injustice in the world if we are not even capable of keeping our own affairs in order?

Ralph Kruger locum general practitioner 105 Newmarket, Isle of Lewis HS1 0ED ralkru@aol.com

1 Holdstock D. Reacting to terrorism. BMJ 2001;323:822. 13 October.)

\section{Response to bioterrorism}

\section{Terror weapons are regarded as weapons} of mass destruction

EDITOR-Wessely et al speculate that a major reason why "armies have generally acquiesced in international treaties to contain" biological and chemical agents is these agents are "particularly ineffective as military weapons [and] have only limited uses." This piece of reasoning does not do justice to the intelligence and serious intent of the drafters and signatories of the 1925 Geneva Protocol, the 1972 Convention on Biological and Toxin Weapons, and the 1993 Chemical Weapons Convention, nor does it explain why spears and stones are not similarly prohibited.

Terror weapons (biological, chemical, and nuclear) are so called not because they are capable of wreaking psychological destruction far in excess of their actual destructive capacity but because their use is considered inherently abhorrent. Somehow, in the collective psyche of our civilised world, killing and maiming with conventional weapons has always been considered more acceptable and less inhumane. Why should that be so?

Unthinkable or not, the events of 11 September 2001 and the subsequent spread of deadly anthrax by civilian post in the United States have upset our mental equilibrium and jolted our complacency. We suddenly realise that international treaties do not bind terrorist bands-they apply only to sovereign states-and international opprobrium will not constrain the individual with a bent mind. Numbed by new talk of a "different" war, and stalked by ominous microbes and suspicious canisters lurking in every shadow, the entire civilised world feels nauseous not because of mass sociogenic illness but because the resort to these weapons proves that, despite all the signs pointing to the progress of the species, man's inhumanity to man has not diminished.

Why do biological, chemical, and nuclear weapons have such an unspeakable quality? Far from being ineffective and limited in use, they invoke feelings of revulsion and strike terror in our minds precisely because we recognise their true potential as weapons of mass destruction. Unlike conventional weapons, they do not leave the victor a hospitable earth to inherit. Weight for weight, and aided by technologically enhanced dispersal mechanisms, deadly pathogens and poisonous gases have the power to wreak as much 
havoc as nuclear bombs and annihilate the human species. Their use raises questions as to whether the human condition can be helped at all.

Meng-Kin Lim associate professor

Department of Community, Occupational and Family Medicine, National University of Singapore, 117597 Singapore

coflimmk@nus.edu.sg

1 Wessely S, Hyams C, Bartholomew R. Psychological implications of chemical and biological weapons. $B M$ 2001;323:878-9. (20 October.)

\section{US anthrax incidents led to scares in Scotland}

EDITOR-Nicoll et al commented on the effect the terrorist attacks in the United States on 11 September 2001 and afterwards have had on public health resources. ${ }^{1}$ We examined the effect of the events on the population of Edinburgh and the Lothians.

In total, 27 incidents involving suspicious packages were notified to public health agencies. Assessments were made in all of these, but only three patients started taking prophylactic antibiotics. These were incidents in which a specific authenticated threat had been received or in which an individual was thought to have been in the United States at a known site of potential exposure.

The figure shows the epidemic curve of incidents involving suspicious packages in Lothian with the dates of fatalities from inhaled anthrax in the United States marked by arrows. ${ }^{2}$ Many of the incidents we dealt with related to postal sorting offices, and the incidents were most frequent in the period surrounding the deaths of two postal workers in Washington, DC, on 21 and 22 October 2001. None of the packages was found to contain any biological agent; most turned out to be false alarms and some were deliberate hoaxes. The episodes showed, however, their ability to produce fear and alarm among ordinary people, which is the ultimate aim of terrorism. ${ }^{34}$

Liaison with the police, laboratory services, and the general public involved in such incidents is a large part of the role of health protection teams in such incidents. We estimate the total number of working hours spent on these incidents over a four week period at 480 . The manpower demands created by them (when added to the existing functions of health protection teams) can threaten to overwhelm public health departments. Collaboration between national agencies and local services is vital to management of the crisis.

Margaret Bree specialist registrar in public health medicine

Margaret.Bree@lhb.scot.nhs.uk

Janet Stevenson consultant in public health medicine Department of Public Health, Lothian NHS Board, Edinburgh EH8 9RS

Janet.Stevenson@lhb.scot.nhs.uk

1 Nicoll A, Wilson D, Calvert N, Borriello P. Managing major public health crises. BMJ 2001:323:1321-2. (8 December.) 2 Centers for Disease Control and Prevention. Update: Investigation of bioterrorism related anthraxConnecticut, 2001. Morb Mortal Wkly Rec MMWR 2001;50:1077-9

3 Wessely S, Hyams C, Bartholomew R. Psychological implications of chemical and biological weapons. $B M J$ 2001:323:878-9. (20 October)

Kerruish T Media could be used to better effect than inducing fear. BMJ 2002;324:115. (12 January.)

\section{Screening for agents of bioterrorism increases terror}

EDIToR-Since 11 September anthrax detection kits for use at home have become available to the general public, trumpeted as offering peace of mind. Extreme care should be taken in promoting these products. They are likely to serve as adjuvants to bioterrorism through identifying falsely positive signals, thus increasing, rather than decreasing, the associated terror and psychogenic illness.

As shown by the events after the postal delivery of anthrax spores in the United States, "the real 'force multiplier' in [biological weapons] is the panic, misinformation, and paranoia." For example, the number of investigations related to anthrax was high, despite the exceedingly low prevalence of disease related to bioterrorism. ${ }^{2}$ Wessely et al advised caution about inadvertently amplifying the psychological response to biological and chemical terrorism. ${ }^{3}$ Interventions aimed at decreasing the panic and misinformation by providing accurate information to populations at risk through public dialogue may be a means of mitigating the psychological response. ${ }^{4}$

Few data are available on the performance characteristics of the anthrax detection kits that can be bought over the counter. They

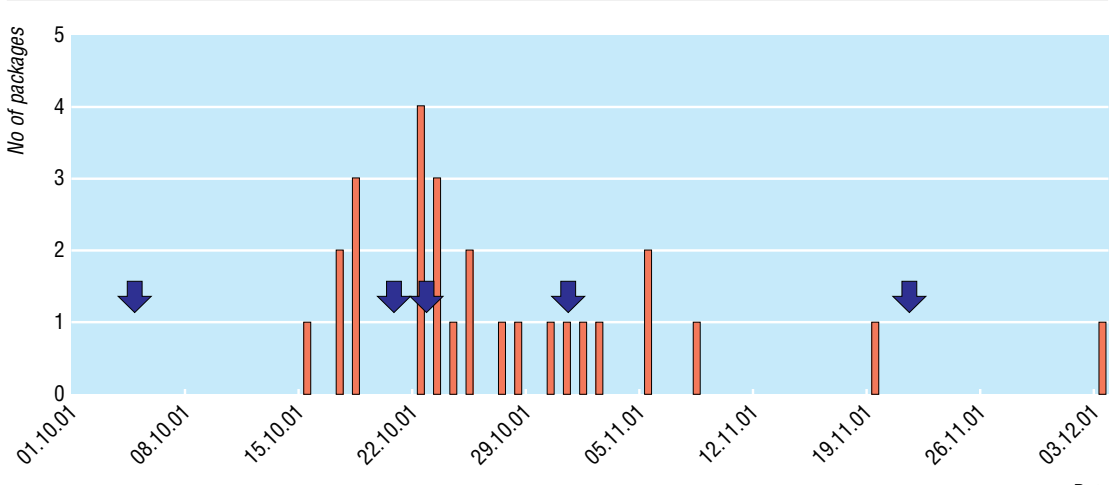

Incidence of suspicious packages in Lothian. Arrows show dates when people died of anthrax in United States are not medical diagnostic tests and are exempt from the approval processes of the United States Food and Drug Administration. The only information available indicates false positive and false negative rates of at least $5 \%$ (sensitivity $<0.95$, specificity $<0.95$ ). ${ }^{5}$ The combination of less than perfect tests and an extremely low prevalence, however, produces some mathematical certainties. Screening for agents of biological terrorism with imprecise tools will yield high ratios of false to true positive results.

Positive results are likely, at least initially, to stimulate investigations of cases or outbreaks, which are not trivial in terms of time, expense, and population anxiety in an already overly extended public health system. Additionally, direct notification of the media about a "positive" anthrax identification by an affected person has the potential for rapid dissemination of mass misinformation with ensuing fear and panic.

Screening for agents of bioterrorism may be impossible with any screening test. Because these agents are rare and profoundly affect the public health, detection must be highly sensitive and timely. To avoid a high rate of false positive results, however, specificity must be high. Screening for anthrax at home is conducted without the benefit of context, which is harmful for rare exposures. Accordingly, there is little place for consumer tests for agents of bioterrorism.

Jonathan L Temte associate professor

Department of Family Medicine, University of Wisconsin, 777 South Mills Street, Madison,

WI 53715, USA

1 Sidell FR, Patrick WC 3rd, Dashiell TR. Jane's chem-bio handbook. Alexandria, VA: Jane's Information Group, 1998

2 Update: investigation of bioterrorism-related anthrax and interim guidelines for clinical evaluation of persons with possible anthrax. MMWR 2001;50:941-8.

3 Wessely S, Hyams KC, Bartholomew R. Psychological implications of chemical and biological weapons: long term social and psychological effects may be worse than term social and psychological effects may be

4 Holloway $\mathrm{HC}$, Norwood AF Fullerton CS, Engel CC, U. Engel CC, Ursano Ry. The threat of biological weapons: prophylaxi and mitigation of psychoog

5 Barnett J. Coming soon: home anthrax test. Available at http://newsweek.msnbc.com (accessed 26 Oct 2001).

\section{Countermeasures against weapons of} mass destruction must be assessed now

EDITOR-Hospitals and healthcare professionals have long planned for disasters and chemical spills, fires and hurricanes, but the terrorist attacks of recent months have led them to re-evaluate their preparedness for disaster and the safety of their countermeasures. Have experiences made people better prepared for chemical and biological weapons of mass destruction? Have the harmful effects of the countermeasures that might be adopted in response to such attacks been examined?

The Gulf war showed that "public health problems not adequately dealt with in the predisaster period are apt to emerge with greater severity during a crisis." Israeli emergency planners preparing for the Gulf war failed to anticipate the complications from wide distribution of protective measures and misuse of masks. ${ }^{3}$ Steady improvements in the quality and safety of gas masks and respirators have helped to reduce the 
complications arising from civil preparedness, especially among those at most risk. ${ }^{4}$ Widespread education initiatives in Israel helped to inculcate not only the dangers of weapons of mass destruction but also the hazards of protective equipment.

Are countries better prepared organisationally today to deal with such weapons? The evidence suggests that they are not. Little has been done to educate the public in the United States or Europe. The recent anthrax crisis in the United States shows how little was known. ${ }^{5}$ Some of the unanswered questions on countermeasures include:

- When should vaccines be given?

- Are vaccines safe for children?

- Which antibiotic should be given and when?

- Should protective masks be distributed and how?

- Is the technology safe?

During the Gulf war 119 deaths in Israel were directly attributed to incorrect use of masks in sealed rooms, especially in vulnerable populations. ${ }^{1}$ Several years were needed to train a population of around 5 million to avoid the life threatening malfunctions of these masks. How long would it take to educate the United Kingdom's 55 million people or the United States' 284 million about using a mask properly?

The threat of states and terrorists using weapons of mass destruction has received increased attention in recent years. Resources need to be dedicated to increase knowledge about these agents and ascertain the effectiveness of countermeasures. Much work is needed to get public health systems ready, and now is the time. Fortunately, the widespread tendency to think that defence against weapons of mass destruction is unnecessary and too difficult is rapidly receding.

Paul Barach assistant professor

Department of Anesthesia and Critical Care, University of Chicago, 5841 South Maryland Avenue, MC 4028, Chicago, IL 60637, USA pbarach@airway.uchicago.edu

1 Barach P, Rivkind A, Israeli A, Berdugo M, Richter E. Emergency preparedness and response in Israel during
the Gulf war: a reevaluation. Ann Emerg Med 1998;32: the Gulf

2 Rivkind A, Eid A, Durst A, Weingart E, Barach P, Richter E. Complications from supervised mask use in postoperative surgical patients during the Gulf war. PreHospital and Disaster Medicine 1999;14:107-8.

3 Hiss J, Arensburg B. Suffocation from misuse of gas mask during the Gulf war. $B M J$ 1992;304:92.

4 Arad M, Epstein Y, Krasner E, Danon Y, Atsmon J. Principles of respiratory protection, aspects and perspectives from the Persian Gulf War. I Chem Warfare Med 1994:2:65-74

5 Investigation of bioterrorism-related anthrax, 2001. MMWR 2001;50:1008-10.

Anthrax issue underlines need for infection specialists trained at bedside

EDITOR-As inconceivable as it might have seemed before 11 September 2001, the public in the United States now shows unprecedented interest in bioterrorism..$^{1-3}$ British press reports make it clear that healthcare services in the United Kingdom must retain the public's confidence in their ability to respond to such crises. ${ }^{2}$
Hart and Beeching's editorial is therefore timely, covering not only the management but also the clinical presentation and diagnosis of anthrax. This point is crucial. With not only anthrax but also the numerous other candidate weapons of war-such as smallpox, tularaemia, plague, and viral haemorrhagic fevers-should doctors not interpret the history, symptoms, and signs of such unfamiliar infections correctly, the consequences could be dire for the patient, and an opportunity to limit the spread of a contagious disease, such as smallpox, could be lost. ${ }^{4}$ Diagnosis will depend on acumen and the quality of the interface between clinicians and microbiologists.

The answer lies in access to appropriate expertise. Given the magnitude of the diagnostic challenge, expertise limited to the end of a telephone may not be the optimal way to conduct business, and accurate recognition and assessment of victims of bioterrorism by physicians with appropriate knowledge acting synergistically with microbiologists would be preferable. Patients could, however, conceivably present at a district general hospital, yet at present physicians with bedside training and accumulated experience in the recognition and management of infectious diseases are rare or absent in many parts of the United Kingdom, even in some teaching centres and medical schools, including many of the newly created ones.

Every specialty claims that its consultant numbers are too low. But there is a way forward. In North America infectious diseases is a large and thriving specialty, combining laboratory microbiology and bedside clinical work. In the United Kingdom, progress towards creating a similar entity has been slow, with specialist registrar training leading towards a certificate of completion of specialist training encompassing both infectious diseases and microbiology or virology. ${ }^{5}$

The current heightened awareness of the potential for a bioterrorism based Armageddon (a possibility that might not recede for a very long time, if ever) is yet another compelling reason to add to the others-for example, increasing long haul tourism, movement of refugees and asylum seekers, multidrug resistant tuberculosis, and new and re-emerging infectious diseases - to accelerate and reinforce the trend towards more doctors being trained in the bedside aspects of infection diseases.

Stephen T Green consultant physician in infectious diseases and tropical medicine

Royal Hallamshire Hospital, Sheffield Teaching Hospitals NHS Trust, Sheffield S10 2JF steve.green@sth.nhs.uk

1 How anthrax can infect and kill. International Herald Tribune 2001; Oct 25:1

Panic attack. Guardian 2001; Oct 18 (www.guardian.co.uk anthrax/story/0,1520,576099,00.html (accessed 21 Jan). 3 Centers for Disease Control and Prevention. Anthrax information and public health emergency preparednes and response. http://www.bt.cdc.gov (accessed 21 Jan).

4 Hart CA, Beeching NJ. Prophylactic treatment of anthrax with antibiotics. BMJ 2001:323:1017-8. (3 November) 5 Public Health. Ba 2001,323:1017-8. (3 November.) Public Health Laboratory Service for England and Wale www.phls.co.uk/whoweare/Training/ (accessed 21 Jan).

\section{Good governance must be introduced globally}

EDITOR-With reference to the letter by Armstrong et al, like all doctors, I too regret the suffering of the people of Afghanistan. But I find the idea of "doctors against war" rather quaint. We need to look at the role of governments in inflicting suffering on their peoples. Zaire (now Democratic Republic of Congo), Somalia, Ethiopia-the list is a long one indeed.

Rather like the NHS, what the world needs is an effective means of implementing good governance-not talking about it, but actually weeding bad government out. We need first to define good governance. This is easier than defining terrorism because the human rights agenda of the United Nations is an excellent starting point. We then need to measure governments' policies and actions against the agreed definition and act when governance is perceived by the United Nations to be either tyrannical or incompetent. Of course, the actions to be taken will be difficult, delicate, and often painful. It is best to care for the poor people of Afghanistan (to name but one country) by ensuring good governance. The concept of noninterference in a country's internal affairs should be scrapped and the UN (suitably reformed) should judge every government periodically. These are difficult issues to grapple with, but if we truly care about the sufferings of whole populations we must begin to globalise good governance.

Dilip DaCruz consultant in emergency medicine Tawam Hospital, Al Ain, United Arab Emirates cruzmissile53@hotmail.com

Armstrong B, Coleman M, Davies C, Elbourne D, Fletcher A. Grundy E, et al. Plight of Afghan people must not be forgotten. BMJ 2001;323:755. (29 September.)

\section{"Functional" should not be shorthand for "I don't know" in dyspepsia}

EDITOR-With reference to the article by Talley et al on dyspepsia, it is saddening to see the perpetuation of the term "functional" as shorthand for "I don't know the nature of the problem." Dyspepsia is the commonest presenting gastrointestinal symptom. Dyspepsia of recent onset, sometimes accompanied by weight loss, rings alarm bells over the possibility of malignancy and dictates the need for endoscopy, but most patients do not fit this paradigm.

The commonest cause of non-malignant dyspepsia is gastro-oesophageal reflux. This is a true functional disorder; acid that should reside in the stomach is retropelled into the oesophagus. A proportion of patients with this disorder will have overt inflammatory damage to the oesophageal mucosa identifiable at endoscopy, but the macroscopic damage is not always easily identified. Many years ago, Baron et al showed that sigmoidoscopic evaluation of possible rectal inflammation was no better than a random decision This is likely to be true for the gullet. 
The accepted causes of dyspepsia are acid related. If endoscopy does not show any acidrelated mucosal damage, then the clinician should move to the next step. The simplest step is a therapeutic trial of treatment with proton pump inhibitors. Alternatively, or if the therapeutic trial is positive, the next step is 24 hour measurement of oesophageal $\mathrm{pH}$.

Most patients will be shown to have acid reflux. Aerophagy usually occurs concomitantly with reflux; patients who have retrosternal discomfort because of acid tend to swallow air in the hope of relieving the discomfort, and this leads to belching. I can recall few, if any, patients with aerophagy who did not have reflux, but I can recall a number of reflux patients in whom the only symptom was belching. The difficult patients with dyspepsia are not those who have functional dyspepsia but the minority who have no evidence of any disturbance of function. These patients have normal endoscopy results and normal $\mathrm{pH}$ values, and they do not respond to treatment with proton pump inhibitors. To label the problems of these patients as functional is an abuse of terminology, as there is no evidence of any disturbance of function. Ready access to a $\mathrm{pH}$ measuring service is mandatory in achieving a diagnosis of the cause of non-malignant dyspepsia. Given the fact that acid reflux is a much more probable cause of dyspepsia than duodenal ulcer, it can be argued that, if there is no reason to suspect malignancy, $\mathrm{pH}$ measurement is a more cost effective first line investigation than endoscopy. It should be available to all clinics dealing with referrals for dyspepsia.

David L Wingate emeritus professor of

gastroenterology

Barts and The London School of Medicine,

London E1 2A]

d.l.wingate@qmul.ac.uk

1 Talley NJ, Phung N, Kalatnar JS. ABC of the upper gastrointestinal tract: indigestion: when is it functional? $B M$ 2001:323:1294-7. (1 December)

\section{Double standards seem to prevail for generic drugs}

EDITOR-The World Trade Organisation tightened legislation on intellectual property by passing the trade related intellectual property rights (TRIPS) agreement in 1995. This was largely facilitated by developed countries. The agreement placed restrictions on manufacturing generic drugs and parallel imports. Article 31 of the agreement allowed an opt out clause at times of national crisis.

South Africa's government thought that, with some 4.7 million citizens infected with HIV, the country had a national crisis and wished to import cheap generic equivalents. Thirty-nine powerful pharmaceutical companies threatened legal sanctions, and the government of the United States censure. Common sense prevailed, and the case was settled out of court after a public outcry.

Recently citizens in the United States became at risk of anthrax, although there were apparently only 15 confirmed cases. Initially the Centers for Disease Control and
Prevention recommended ciprofloxacin as the antibiotic of choice, although other antibiotics may be effective, and CDC now recommends doxycycline. On the basis of the initial recommendation the Bush administration threatened Bayer with the United States buying generic equivalents. Although the politics and legalities are complex, superficially the whole issue smacks of double standards.

Graham Howarth associate professor University of Pretoria, Suite 21, P/Bag X 87, Bryanston 2021, South Africa ghowarth@kalafong.up.ac.za 1 Charatan F. Bayer cuts price of ciprofloxacin after
Bush threatens to buy generics. BMJ 2001;323:1023 (3 November.)

\section{Patient safety is more important than efficiency}

EDIToR-In his letter Isaac, a staff anaesthesiologist in the United States, suggests the establishment of outpatient surgical facilities. ${ }^{1}$ I am well aware that "office surgery" has been heavily promulgated recently in the United States on the grounds of "efficiency," financial or otherwise.

In the United Kingdom general anaesthesia as an outpatient in the dental surgery was a constant feature for many years. Most of the original bickering concerned the low fees paid to the administrator of the anaesthetic. After 1959 concern focused more on safety. Committees were formed, commissions appointed, and working parties convened. All made recommendations, but sporadic, usually avoidable, deaths in dental surgeries continued to occur.

I participated in several discussions, and it was plain that the solution of banning general anaesthesia in dental surgeries was unacceptable because of the effect on the income of the dentist (who often used to administer the anaesthetic) and the "anaesthetist," where this was an attending doctor, often a general practitioner. It was not until 1999, after yet more deaths, that the British government took the decision to ban general anaesthesia in dental surgeries. It seems ironic that it took the United Kingdom 40 years to accept that general anaesthesia is safest when given in a fully equipped and fully staffed facility when there seems to be an increasing interest in office based surgery and anaesthesia on the other side of the Atlantic.

Boulton has given a fascinating account of the story of anaesthesia in the dental surgery. ${ }^{2}$ It would be sad to see the problems resurface in the name of efficiency. Patient safety is more important than efficiency.

John S M Zorab consultant anaesthetist emeritus, Frenchay Hospital Bristol

Holmray Cottage Park Street, Iron Acton Bristol, BS37 9UJ

JZorab@compuserve.com

1 Isaac P. Approach to surgery in United Kingdom should be shaken up. BMJ 2001;323:106. (14 July.)

2 Boulton TB. The Association of Anaesthetists of Great Britain and Ireland 1932-1992 and the development of the specialty of anaesthesia. London: Association of Anaesthetists of Great Britain and Ireland, 1999.

\section{Parents are the best judges of school attendance}

Editor-Barnes et al describe school absence in the week after a minor injury on a Sunday as unnecessary, but on what grounds?' ${ }^{1}$ Three months ago on another Sunday morning I was taken to the emergency department after being knocked off my bike. I had soft tissue bruises, a sprained hand, and various abrasions. Had I been a schoolchild in south Wales, I would have been eligible to participate in Barnes's study.

I did return to work the following day in considerable pain and discomfort. I was only able to do so for three reasons. First, I had control over my work pattern. I could rearrange appointments, avoid prolonged standing, etc. Second, I had control over my work environment. I could elevate my leg while sitting, ask people to come to see me rather than going to see them, etc. Finally, I had control over when and how many analgesics I swallowed. None of these options is open to schoolchildren.

As doctors, especially paediatricians, we should have realised by now that patients and their families are there to be listened to and learnt from. The parents of these children understood their children, knew the school conditions, and saw at first hand the consequences of the injury. They were in a much better position to judge what was in their child's best interests than their doctors. School absence may be an undesirable consequence of minor injury in children, but unnecessary?

Richard Reading consultant community paediatrician Norfolk and Norwich University Hospital, Norwich NR4 7UY

r.reading@uea.ac.uk

1 Barnes PM, Price L, Maddocks L, Lyons RA, Nash P, McCabe M. Unnecessary school absence after minor injury: case-control study. BMJ 2001;323:1034-5. (3 November.)

\section{Use of digitalisize and digitalize}

EDITOR-Aronson makes a good case for using the dreaded $\mathrm{z}$ when spelling words. But I know I shall be resistant, having long struggled to expunge the Americanisms from my spellchecker. Why not accept the French influence?

But digitalize? When using digitalis surely we should digitalisize. This would leave us free to digitalize when treating the patient as a number rather than a person and to digitize when examining the rectum.

Richard James senior lecturer, University of Westminster

Integrative Healthcare, London W1G 7LA richard@integrativehealthcare.co.uk

1 Aronson J. When I use a word: -ize right. BMJ 2001;323: 1173. (17 November.)

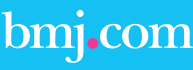

\section{Rapid responses}

Correspondence submitted electronically

is available on our website 